\title{
Inhibition of egg development and implantation in rats after post-coital administration of the progesterone antagonist RU 486
}

\author{
A. Psychoyos and I. Prapas \\ Laboratoire de Physiologie de la Reproduction UA 549 CNRS, Hôpital de Bicêtre, \\ Bâtiment INSERM, 78 avenue du Général Leclerc, Le Kremlin-Bicêtre, France
}

\begin{abstract}
Summary. RU 486 was administered to rats on Day 1 or Days $1+2$ of pregnancy. Endometrial sensitivity (i.e. decidualization in response to oil instillation) was delayed by $2.5 \mathrm{mg} / \mathrm{kg}$ injected s.c. on Day 1 , and almost half of the animals also exhibited a delay in implantation of 1-2 days. Higher doses $(5$ or $10 \mathrm{mg} / \mathrm{kg}$ ) administered on Days $1+2$ reduced the number of implantations to zero in all animals. Apparently normal morulae were found up to the evening of Day 4 in the oviduct and/or the uterus of most animals. However, on the morning of Day 5, ova were detected in only $25 \%$ of the animals and all were in the uterus: none was at the blastocyst stage and they appeared to be degenerated or compacted morulae. Egg survival and rate of egg recovery from the uterus was not improved by early ovariectomy, showing that this antiprogestagen acts on these events independently of the presence of circulating oestrogens.
\end{abstract}

\section{Introduction}

Prevention of implantation of blastocysts by hormones or related substances which affect the hormonal regulation of this process has been explored intensively during the past decades. Oestrogens and/or progestagens as well as their antagonists can induce local imbalances affecting the endometrial preparation and development of an appropriate uterine 'milieu'. In such studies, the rat and mouse are used preferentially as 'pilot' species because so much is already known about their reproductive processes, implantation in particular (Psychoyos, 1973; Finn, 1977).

Implantation in the rat follows a precise time course of hormonal conditioning: a progesterone priming for about $48 \mathrm{~h}$ which then allows, a few hours later, oestrogen to induce a short phase of endometrial receptivity, the so called "implantation window" (Psychoyos \& Martel, 1985). Under normal conditions, the necessary 48 -h preparation of the endometrium by progesterone seems to start by the evening of Day 2 of pregnancy (Day $1=$ day of mating), and is completed by the evening of Day 4. Oestrogen availability at the latter time induces the receptive phase which appears around 12:00 h of Day 5 (Psychoyos, 1973). Anti-oestrogens or anti-progestagens administered early in pregnancy may interfere with implantation by altering the normal pattern of this hormonal conditioning.

In a series of experiments, the results of which we report here, we have studied the effects on uterine receptivity and implantation of a potent synthetic antiprogestagen, RU 486 . We have focussed this study in particular on the changes in the timing of endometrial receptivity, induced after an early treatment by this compound, as well as its effect on the future of the fertilized ova. A preliminary account of this study has been reported elsewhere (Psychoyos, 1986). 


\section{Materials and Methods}

Adult virgin female rats of the Wistar strain, weighing $220-250 \mathrm{~g}$, were housed at room temperature of $23-25^{\circ} \mathrm{C}$ under controlled illumination of $14 \mathrm{~h}$ light and $10 \mathrm{~h}$ darkness, with 13:00 h as the midpoint of the light phase. Water and pelleted food were supplied ad libitum. The females were caged overnight with males of proven fertility and separated the following morning. Insemination was determined by the presence of spermatozoa in the vaginal smears, taken at the time of separation. The day on which spermatozoa were found was designated Day 1 of pregnancy. RU 486 (Roussel Uclaf, Romainville, France) was suspended in sesame oil and administered subcutaneously in a volume of $0.2 \mathrm{ml} / \mathrm{rat}$. Operations were performed under semi-sterile conditions using ether anaesthesia. Removal of the oviducts or subcapsular ovariectomies leaving the oviduct intact, were done under a stereomicroscope, through dorso-lateral incisions. Animals that were laparotomized or killed after Day 4 received $1 \mathrm{ml} 0.5 \%$ Evans blue in $0.9 \%(\mathrm{w} / \mathrm{v})$ sodium chloride $15 \mathrm{~min}$ before laparotomy or autopsy in order to localize the implantation sites (Psychoyos, 1971). Ova were collected from the oviducts and/or the uterine horns by flushing them with Tyrode's solution (Gibco, Flobio, Courbevoie, France). Induction of artificial decidualization was performed by intraluminal instillation of $0.1 \mathrm{ml}$ sesame oil.

Study $I$. The rats were treated on Day 1 or Days 1 and 2 of pregnancy with $2.5 \mathrm{mg}, 5 \mathrm{mg}$ or $10 \mathrm{mg} \mathrm{RU} 486 / \mathrm{kg}$. They were laparotomized on Day 6 and killed on Day 10 to assess the total number of implanted embryos.

Study II. The animals received sesame oil only or $2.5,5$ or $10 \mathrm{mg} \mathrm{RU} 486 / \mathrm{kg}$ on Day I of pregnancy. On Day 2 one of the oviducts was removed in order to obtain a 'sterile' horn and sesame oil was injected into the ipsilateral uterine horn on Day 7. All animals were killed $96 \mathrm{~h}$ after the intraluminal oil injection to assess the number of implantations in the normal horns and weight of the 'sterile' horns.

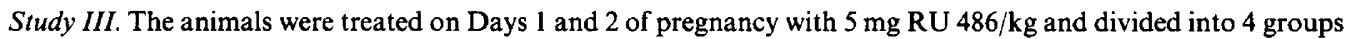
which were killed (1) at 11:00 h on Day 3, (2) at 11:00 h or (3) at 17:00 h on Day 4; or (4) at 11:00 h on Day 5. Two groups of untreated animals, serving as controls, were killed (1) at 11:00 h or (2) at 17:00 h on Day 4. In each animal the presence of ova was checked in the oviducts and uterine horns separately.

Study IV. The rats in this study received $5 \mathrm{mg}$ RU 486/kg on Day 2 of pregnancy and were divided into 3 groups of 8 animals each: (1) non-ovariectomized controls, (2) ovariectomized on Day 2, and (3) ovariectomized on Day 4 at I1:00 h. Two groups of 6 untreated animals served as controls: (1) ovariectomized on Day 2 and (2) ovariectomized on Day 4 at 11:00 h. All animals were killed on Day 5 between 09:00 and $11: 00 \mathrm{~h}$ and their oviducts and uterine horns were searched for the presence of ova as in Study III.

\section{Results}

The results of Study I are shown in Table 1. Treatment with RU 486 once on Day 1 of pregnancy exerted an anti-implantation effect proportional to the administered dose of the anti-progestagen. However, such a treatment appeared to induce a delay in implantation in several animals in all groups. The number of implantations recorded at autopsy on Day 10 was therefore higher than the

Table 1. Effect of RU 486 on implantation in rats treated s.c. on Days 1 or $1+2$ post coitum

\begin{tabular}{lcccccccc}
\hline & & & \multicolumn{2}{c}{ Day 6* } & & \multicolumn{2}{c}{ Day 10* } \\
\cline { 7 - 8 } \cline { 6 - 7 } $\begin{array}{l}\text { Dose } \\
(\mathrm{mg} / \mathrm{kg})\end{array}$ & $\begin{array}{c}\text { Day of } \\
\text { treatment }\end{array}$ & $\begin{array}{c}\text { No. of } \\
\text { animals }\end{array}$ & $\begin{array}{c}\text { \% blue } \\
\text { positive }\end{array}$ & $\begin{array}{c}\text { Total no. of } \\
\text { blue sites }\end{array}$ & & $\begin{array}{c}\% \\
\text { pregnant }\end{array}$ & $\begin{array}{c}\text { Total no. of } \\
\text { implantations }\end{array}$ \\
\hline $2 \cdot 5$ & 1 & 13 & 69 & 78 & & 76 & 119 \\
5 & 1 & 12 & 41 & 18 & & 50 & 26 \\
10 & 1 & 11 & 18 & 4 & & 27 & 7 \\
$2 \cdot 5$ & $1+2$ & 8 & 25 & 4 & & 25 & 9 \\
5 & $1+2$ & 8 & 12 & 3 & & 0 & 0 \\
10 & $1+2$ & 8 & 0 & 0 & & 0 & 0 \\
Control & & 11 & 100 & 140 & & 100 & 140 \\
\hline
\end{tabular}

*Implantation sites were assessed by the intravenous injection of Evans Blue 15 min before laparotomy on Day 6 or autopsy on Day 10.

†Percentage of animals with blue dye sites. 
number of blue spots observed on Day 6, and the percentage of animals implanting between Days 6 and Day 10 were also higher. Treatment with $2.5 \mathrm{mg} \mathrm{RU} \mathrm{486/day} \mathrm{on} \mathrm{Days} 1$ and 2 of pregnancy was more clearly inhibitory to implantation and caused some delay of implantation. However, higher doses given on Days 1 and 2 were totally inhibitory.

Study II was performed to examine the possibility that treatment on Day 1 induces a change of uterine receptivity. In fact, as shown in Table 2, the intraluminal instillation of oil into the 'sterile' horn of the animals treated with RU 486 was able to induce a strong decidual reaction, whereas the same procedure remained ineffective in untreated controls. Rats treated with a low $(2.5 \mathrm{mg} / \mathrm{kg})$ or a high $(10 \mathrm{mg} / \mathrm{kg})$ dose of RU 486 exhibited a decidual response of considerable magnitude but the number of implantations decreased with the highest dose administered.

Table 2. Effect of various doses of RU 486, injected s.c. on Day 1 of pregnancy, on the timing of uterine receptivity in the rat

\begin{tabular}{lccccc}
\hline & \multicolumn{2}{c}{ Normal horn* } & & 'Sterile' horn* \\
\cline { 2 - 3 } $\begin{array}{l}\text { Dose } \\
(\mathrm{mg} / \mathrm{kg})\end{array}$ & $\begin{array}{c}\text { No. with } \\
\text { implantations/ } \\
\text { total no. }\end{array}$ & $\begin{array}{c}\text { Total no. of } \\
\text { implantations }\end{array}$ & & $\begin{array}{c}\text { No. with } \\
\text { deciduomata }\end{array}$ & $\begin{array}{c}\text { Mean wt of } \\
\text { decidualized horns } \\
(\mathrm{mg})\end{array}$ \\
\hline $2 \cdot 5$ & $5 / 6$ & 27 & & $5 / 6$ & 774 \\
5 & $3 / 4$ & 7 & $3 / 4$ & 683 \\
10 & $1 / 6$ & 3 & $5 / 6$ & 648 \\
Control & $6 / 6$ & 38 & & $0 / 6$ & \\
\hline
\end{tabular}

*On Day 2 one of the oviducts was removed to obtain a 'sterile' horn and sesame oil was injected into this horn on Day 7 (see text).

Table 3. Effect of RU $486(5 \mathrm{mg} / \mathrm{kg} \mathrm{s.c.} \mathrm{on} \mathrm{Days} 1$ and 2 of pregnancy) on tubal transport in the rat

\begin{tabular}{lccc}
\hline & & \multicolumn{2}{c}{$\begin{array}{c}\text { No. of animals } \\
\text { with embryos in: }\end{array}$} \\
$\begin{array}{l}\text { Day of } \\
\text { autopsy }\end{array}$ & $\begin{array}{c}\text { No. of } \\
\text { animals }\end{array}$ & Oviduct & Uterus \\
\hline $3(11: 00 \mathrm{~h})$ & 8 & 7 & 0 \\
$4(11: 00 \mathrm{~h})$ & 8 & 7 & 5 \\
$4(17: 00 \mathrm{~h})$ & 8 & 1 & 6 \\
$5(11: 00 \mathrm{~h})$ & 8 & 0 & 2 \\
$4(11: 00 \mathrm{~h})$ & $8^{*}$ & 8 & 0 \\
$4(17: 00 \mathrm{~h})$ & $8^{*}$ & 7 & 1 \\
\hline
\end{tabular}

*Untreated controls.

The results of Study III appear in Table 3. Fertilized ova were present on Day 3 in the oviduct. However, by the morning of Day 4, more than $60 \%$ of the animals treated with RU 486 had ova in the oviduct and uterus. Among the untreated animals only 1 had ova in the uterus at 17:00 h. At this time most of the treated animals had ova located in the uterus only. Under normal conditions the passage of ova from the oviduct to the uterine cavity begins on the evening of this day (Wu et al., 1971; Forcelledo et al., 1981). On the morning of Day 5, however, ova were detected only in about $25 \%$ of the treated animals and all were in the uterus. None of them was at the blastocyst stage and showing cavitation, and in general the aspect of the ova recovered from this group was that of degenerated or compacted morulae. 
Study IV was undertaken to determine (1) the effect of a single administration of the antiprogestagen on Day 2 of pregnancy and (2) the repercussions on this effect of an early ovariectomy. In all animals of the three groups treated with RU 486 in this study, no blastocysts were recovered on Day 5 from the oviduct or the uterus. Of 8 animals from Group 1 (not ovariectomized) and 8 animais from Group 2 (ovariectomized on Day 2), 2 and 3 respectively had morulae in the uterus, but most of these appeared damaged. No ova were found in any animal of Group 3 (ovariectomized on Day 4). Among the untreated controls, 4 out of 6 animals ovariectomized on Day 2 and all of those ovariectomized on Day 4 had normal blastocysts in the uterus.

\section{Discussion}

As shown by the results described above, RU 486 affects early pregnancy in different ways depending on the amount administered and the day of its administration. Given on Day 1 it may lead to a marked decrease in the number of implanting embryos and the percentage of animals showing implantations. However, several of the implantations occurring under these conditions were delayed. As already mentioned, progesterone preparation of the endometrium seems to start by the evening of Day 2 of a normal pregnancy in the rat. Administration of antiprogestagen on Day 1 is assumed to cause delayed implantation by changing the 'starting-point' of the pre-nidatory priming of the endometrium by progesterone. The occurrence of endometrial receptivity could therefore be displaced for 1-2 days. Such a change was also observed with RU 486 treatment in the animals of our Study II, in which the endometrial sensitivity for decidualization was manifested at a time when, under normal conditions, it should have been absent. In fact, the intraluminal instillation of oil induces a decidual response when applied on Day 5 of a normal pregnancy, but fails to do so on the following days (De Feo, 1967; Finn, 1977). Similarly, blastocysts transferred into the uterus of normal pseudopregnant rats beyond the chronological limits of uterine receptivity fail to implant, degenerate and are expelled through the vagina (Dickmann \& Noyes, 1960; Psychoyos, 1973; Psychoyos \& Casimiri, 1981). However, blastocysts transferred on Day 7 post coitum into the uteri of animals treated on Day 1 with RU 486 may implant (A. Psychoyos \& I. Prapas, unpublished data). Whether the successful induction of decidualization and implantation beyond the chronological limits of uterine receptivity induced by the anti-progestagen is due to a displacement of these limits, or to an enlargement of the narrow opening of the "implantation window" remains to be determined. In any case, such a property of RU 486 and/or other anti-progestagens could be of clinical interest if they could be used to displace or enlarge the "implantation window" in women after replacement of embryos from in-vitro fertilization.

A similar shift in uterine receptivity appears to occur after a low, as well as after a high $(10 \mathrm{mg} / \mathrm{kg})$, dose of antiprogestagen. However, the percentage of implanting embryos itself is greatly affected by doses higher than $2.5 \mathrm{mg} / \mathrm{kg}$ and by varying the day of administration. Therefore, $5 \mathrm{mg} / \mathrm{kg}$, given once on Day 2, reduces this rate to zero. Furthermore, as indicated by the results of our Studies III and IV, this appears to be due to an effect of the anti-progestagen on egg survival and maintenance in the uterus occurring at the transition step of the morula to the blastocyst stage. An arrest at this step of egg development has been observed in mice, after treatment on Day 2 of pregnancy with antiprogesterone monoclonal antibodies (Wang et al., 1984).

The obvious acceleration of tubal egg transport that we observed in the animals treated by RU 486 could be considered as a consequence of an hormonal imbalance which favours the predominance of oestrogens. However, as shown by the results of Study IV, egg survival and the rate of their recovery from the uterus was not improved by early ovariectomy. The effect of the anti-progestagen on these events therefore appears to occur independently of the presence of circulating oestrogens.

It is not yet known whether the early embryo possesses intracellular receptors to progesterone. If this is the case, RU 486 could act directly upon the egg as a progesterone competitor. However, 
our preliminary observations show no such effect of this compound on embryonic development in vitro. One could therefore consider as more likely an indirect effect of the anti-progestagen on egg survival through changes in endometrial functions and the composition of the intraluminal 'milieu' in particular. Whatever the mechanism, the detrimental effect of RU 486 on egg survival and maintenance in utero, reported in this paper, shows the high potential of anti-progestagens as agents for inducing interception.

This work was supported by the Institut National de la Recherche Médicale (Grant No. 834014) and the Rockefeller Foundation. We thank Dr D. Philibert of the Centre de Recherche Roussel UCLAF for providing the RU 486.

\section{References}

De Feo, V.J. (1967) Decidualization. In Cellular Biology of the Uterus, pp. 191-290. Ed. R. M. Wynn. Appleton-Century-Crofts, New York.

Dickmann, Z. \& Noyes, R.W. (1960) The fate of ova transferred into the uterus of the rat. J. Reprod. Fert. 12, 197-212.

Finn, C.A. (1977) The implantation reaction. In Biology of the Uterus, pp. 245-308. Ed. R. M. Wynn. Plenum Press, New York.

Forcelledo, M.L., Vera, R. \& Croxatto, H.B. (1981) Ovum transport in pregnant, pseudopregnant and cyclic rats and its relationship to estradiol and progesterone blood levels. Biol. Reprod. 24, 760-765.

Psychoyos, A. (1971) Methods for studying capillary changes of the endometrium. In Methods in Embryology, pp. 334-338. Ed. J. C. Daniel. W. H. Freeman and Company, San Francisco.

Psychoyos, A. (1973) Endocrine control of egg-implantation. In Handbook of Physiology: Endocrinology, Vol. 2, pp. 187-215. Eds R. O. Greep \& E. B. Astwood. American Society of Physiology, Washington, DC.
Psychoyos, A. (1986) Uterine receptivity for nidation. Annls. N.Y. Acad. Sci. 476, $36-42$.

Psychoyos, A. \& Casimiri, V. (1981) Uterine blastotoxic factors. In Cellular and Molecular Aspects of Implantation, pp. 327-334. Eds S. R. Glasser \& D. W. Bullock. Plenum Press, New York.

Psychoyos, A. \& Martel, D. (1985) Embryo-endometrial interactions at implantation. In Implantation of the Human Embryo, pp. 195-218. Eds R. G. Edwards, J. M. Purdy \& P. C. Steptoe. Academic Press, London.

Wang, M.Y., Rider, V., Heap, R.B. \& Feinstein, A. (1984) Action of anti-progesterone monoclonal antibody in blocking pregnancy after postcoital administration in mice. $J$. Endocr. 101, 95-100.

Wu, J.T., Dickmann, Z. \& Johnson, D.C. (1971) Effects of ovariectomy or hypophysectomy on day one of pregnancy on development and transport of fertilized rat eggs. J. Endocr. 49, 507-513.

Received 9 October 1986 